\title{
Perancangan Buku Interaktif dalam Meningkatkan “Self-Esteem” Sebagai Upaya Pencegahan "Bullying" Pada Anak Usia 7-9 Tahun
}

\author{
Tirza Amelia Hartono' ${ }^{1}$, Wibowo ${ }^{2}$, Rika Febriani ${ }^{3}$ \\ ${ }^{13}$ Program Studi Desain Komunikasi Visual, Fakultas Seni dan Desain, Universitas Kristen Petra, \\ Surabaya \\ ${ }^{2}$ Program Studi Desain Komunikasi Visual, Fakultas Seni Rupa, Institut Seni Indonesia, Jogjakarta \\ tirzaameliaa@gmail.com
}

\begin{abstract}
Bullying case become more common nowadays in Indonesia. Bullying can be found easily even among elementary school students. Yet, the psychological effect of bullying on childrens can last for their whole life. Thus, self-esteem is very important and needs to be developed since very young age to prevent bullying on children. Before being the victim or doer of bullying, child should learn to improve their selfesteem. Through the design of this book, child can realize that bullying is wrong and know how to react and respond to bullying act. Hopefully, this book can help the society for creating a better generation with better social life interactions.
\end{abstract}

Keywords: Interactive, book, bullying, self-esteem, children

\section{PENDAHULUAN}

Bullying bisa menghancurkan harga diri, mengganggu kestabilan emosi serta mengurangi rasa percaya diri anak kedepannya. Salah satu ciri khusus pada anak yang menjadi korban bullying, adalah korban mempunyai tingkat self-esteem yang relatif rendah. Hal itu disebabkan karena para pelaku bullying secara terus menerus menghina, mengancam, dan berkata tidak pantas pada korban; atau para pelaku tidak pernah dan tidak mau mengakui kelebihan (baik fisik maupun non-fisik) yang dimiliki oleh korban.

Hal ini mengakibatkan ketakutan, hilangnya rasa percaya diri, dan hilangnya kemampuan untuk berespons dan bertindak pada korban bullying. Hal yang terparah yang bisa terjadi adalah anak menjadi depresi hingga dapat memutuskan untuk mengakhiri hidupnya karena gambar dan harga diri yang rusak akibat dari bullying. Sedangkan pada pelaku bullying, pelaku juga memiliki pemahaman moralitas yang kurang, sehingga tidak memikirkan perbuatan yang dilakukan bernilai baik atau buruk.

Banyak dari orangtua tidak tahu bagaimana cara mengatasi anak yang menjadi korban maupun pelaku bullying. Padahal peran orang tua dalam mendampingi dan mendidik anak, terutama pada usia dini, sangatlah penting. 
Self-esteem pada anak sangat penting dan perlu dibangun sejak dini sebagai langkah preventif terhadap bullying pada anak Ketika anak mempunyai tingkat self-esteem yang tinggi mereka akan terhindar dari pelaku bullying. Menurut Mengantes (2005:23) anak yang mempunyai selfesteem mereka akan cenderung bisa mengatur tingkah lakunya untuk mendapatkan pengakuan dan rasa hormat dari orang lain tidak dengan menyakiti temannya. Anak yang mempunyai self-esteem tinggi akan mempunyai perasaan berhaga terhadap dirinya sendiri dan dapat menerima pujian dan kritik sebagai masukan. Anak akan mempunyai nilai postif yang ada di dalam dirinya walaupun mungkin ia berbeda dari yang lain. Bahkan tanggapan orang lain dapat menjadi sebuah umpan balik untuk memperbaiki dirinya sendiri.

Dengan mengajarkan anak self-esteem anak akan mengerti bagaimana harus bersikap dan menghargai orang lain seperti ia menghargai dirnya sendiri. Dengan cara itulah diharapkan perilaku bullying dapat dihindarkan.

Sedangkan untuk menyampaikan pesan ke anak dibutuhkan media yang menarik agar anak tidak mudah untuk bosan dan dapat membuat proses penyerapan informasi menjadi lebih mudah dan menyenangkan.
Media yang dibuat berupa buku interaktif. Buku sebagai sarana penunjang pengembangan diri anak. Lewat buku anak akan banyak belajar bagaimana berkonsentrasi dan berimajinasi dalam memaknai alur cerita serta membantu meningkatkan minat baca anak. Dengan buku interaktif anak dapat ikut berperan aktif dalam pembelajaran dan disediakan sarana interaktif seperti pop-up, lift the flap, touch and feel book atau bisa juga pull tab books agar anak lebih fun dalam membaca sehingga materi yang diberikan dapat diterima secara efektif. Dibutuhkan pendamping seperti orang tua atau guru untuk mendampingi anak dalam memaknai isi cerita.

Berdasarkan dari masalah yang didapatkan dari tinjauan lapangan usulan pemecahan masalah adalah berupa buku interaktif dalam meningkatkan self-esteem sebagai upaya pencegahan kasus bullying pada anak usia 7-9 tahun. Berdasarkan wawancara ditemukan bahwa umur 7 adalah umur yang tepat untuk memulai mengajarkan anak tentang self-esteem. Pada usia ini anak berupaya semakin ingin mengenal siapa dirinya dengan mencari teman. Anak sudah belajar mengenal konsep moralitas, seperti kejujuran, keadilan dan kehormatan, hal ini dapat membantu dalam upaya menanamkan moral-moral yang tepat agar mereka bisa 
lebih mudah mengnanamkan self-esteem sebagai upaya terhindar dari prilaku bullying.

\section{METODE PENELITIAN}

Dalam tugas akhir Perancangan Buku Interaktif dalam Meningkatkan "SelfEsteem” Sebagai Upaya Pencegahan "Bullying" Pada Anak Usia 7-9 Tahun ini peneliti menggunakan beberapa metode perancangan diantaranya sebagai berikut:

\section{Metode Pengumpulan Data}

Data yang digunakan untuk menyusun Perancangan Buku Interaktif dalam Meningkatkan "Self-Esteem” Sebagai Upaya Pencegahan "Bullying" Pada Anak Usia 7-9 tahun ini berasal dari sumber data primer dan sekunder. Sumber primer adalah sumber data dari pihak yang langsung bersangkutan ataupun dari wawancara terhadap koresponden. Sedangkan data sekunder adalah data yang berasal dari sumber data yang telah dipublikasikan ke umum seperti buku atau dokumen. Proses pengumpulan data ini menggunakan beberapa metode di antaranya:

\section{a. Wawancara}

Wawancara mendalam akan dilakukan kepada psikolog untuk mendapatkan pandangan ahli mengenai bullying. Dilakukan juga wawancara dengan orang tua dari anak yang pernah mengalami bullying di sekolah.

\section{b. Metode Kepustakaan}

Metode ini adalah dengan cara mengkaji informasi dari media cetak berupa buku, koran, majalah, dan jurnal. Ini merupakan teknik observasi secara tidak langsung.

\section{c. Internet}

Metode ini dilakukan dengan penelitian data yang ada melalui internet. Data tersebut biasanya berupa artikel atau data-data mengenai bullying.

\section{Metode Analisis Data}

Metode yang digunakan bersifat deskriptif kualitatif. Data kualitatif yang diperoleh dari hasil observasi antara peneliti dan responden adalah berupa data verbal. Analisa data dilakukan dengan menggunakan metode 5W1H yang berisi kalimat pertanyaan berupa: What, Who, When, Where, Why dan How. Juga dilakukan analisis SWOT. Tujuan dari analisa tersebut agar dapat merumuskan strategi yang tepat dalam perancangan ini. Analisis SWOT didasarkan pada logika yang dapat memaksimalkan kekuatan (Strengths) dan peluang (Opportunities), namun secara bersamaan dapat meminimalkan kelemahan (Weaknesses) dan ancaman (Threats). Dari 
hasil analisa data tersebut ditarik kesimpulan agar peneliti mengetahui benar mengenai permasalahan yang ada menciptakan solusi yang tepat.

\section{What}

Permasalahan apa yang diangkat dalam membuat perancangan ini?

Perancangan ini diangkat dari tema bullying. Berdasarkan fenomena yang sering terjadi di lingkungan namun masih kurang mendapat perhatian masyarakat padahal dampaknya sangat besar bagi tumbuh kembang anak. Dengan adanya kasus bullying maka dibutuhkan penanaman selfesteem sejak dini agar anak bisa tahu bagaimana bisa menghargai dirinya sendiri dan menghargai orang lain sebagai makhluk sosial sebelum anak terlibat dengan kasus bullying.

\section{Who}

Siapa sasaran dari perancangan ini?

Sasaran dari perancangan ini adalah anak yang berumur 7-9 tahun golongan menengah keatas. Usia ini diambil berdasarkan riset bahwa saat ini di sekolah-sekolah sudah mulai mengadakan pendidikan pembangunan karakter anak sejak usia 7 tahun. Usia 7-9 tahun adalah usia yang strategis dan memiliki peran penting dalam meletakkan dasar-dasar untuk pembentukan fondasi anak yang seutuhnya dan pengembangan pendidikan karakter serta pengembangan kemampuan lainnya sehingga anak siap untuk memasuki jenjang pendidikan selanjutnya (Piaget, 2008). Pemilihan usia ini juga didasari fakta bahwa penanganan yang semakin cepat maka semakin baik. Sehingga merupakan waktu yang tepat untuk meletakkan dasardasar Self-esteem sebagai upaya untuk menghindari kasus bullying.

\section{Where}

Dimana hasil perancangan ini ditempatkan agar dapat dilihat oleh khalayak pasaran yang dimaksud?

Hasil perancangan buku interaktif ini akan di jual di toko buku dan dijual secara online sebagai upaya agar menjangkau semua masyarakat. Buku ini juga akan dipasarkan ke perpustakaan sekolah-sekolah baik menengah atas maupun menengah kebawah agar dapat menjangkau semua kalangan. Mengingat bahwa bullying adalah kasus yang umum terjadi di mana saja.

\section{When}

Kapan waktu yang tepat untuk memasarkan buku ini?

Buku ini akan dijual dipasaran pada waktu liburan panjang kenaikan kelas. Pada saat itu anak sering mencari berbagai bentuk hiburan 
dan orang tua bisa membelikan buku ini sebagai sarana pengisi liburan mereka.

5. Why

Kenapa perancangan ini perlu untuk dirancang?

Tidak banyak orang tahu bahwa bullying bukanlah masalah kecil. Bullying bisa menghancurkan masa depan anak tidak hanya dengan korban namun juga pelaku. Dari hal itu bisa dilihat bullying dapat menghancurkan masa depan seseorang. Dengan mengajarkan self-esteem yang baik pada anak tentang bagaimana anak harus bersikap dengan dirinya dan orang lain bisa membuat anak terhindar dari kasus bullying. Diharapkan perancangan ini juga dapat menciptakan kehidupan sosial yang baik kedepannya.

\section{How}

Bagaimana membuat perancangan yang menarik dan dapat menanamkan self-esteem sebagai upaya pencegahan dari bullying? Anak mungkin tidak sadar pernah melakukan bullying maka digunakan contoh yang biasa akrab terjadi dilingkungan sekolah berbasis cerita sehari-hari. Anak akan mengetahui bahwa tindakan tesebut adalah salah, selain itu anak juga akan mengerti bagaimana tetap percaya diri dengan segala keunikan yang ada dalam dirinya. Menanamkan sikap pada anak bahwa menjadi dirinya sendiri adalah yang terbaik dan beberapa juga disisipi nilai-nilai moral sebagai bentuk agar terhindar dari bullying.

- Strength

- Kebanyakan buku bullying hanya mengajarkan secara teori tentang apa itu bullying.

- Akar bullying sudah ada sejak anak menginjak sekolah dasar.

- Masih belum banyak buku di Indonesia yang mengajarkan anak tentang selfesteem

- Dengan mengajarkan self-esteem pada anak merupakan suatu "jalan keluar" sebelum anak terlibat prilaku bullying.

- Buku adalah media dimana anak bisa belajar untuk lebih berkonsentrasi, berimajinasi dan menambah.

- Multimedia menyebabkan anak menjadi ketergantungan dan menimbulkan dampak yang negatif bagi anak.

- Dengan adanya sarana interaktif anak akan lebih melatih daya imajinasi dan tidak membosankan bagi anak.

- Weakness

- Budaya dengan metode pembelajaran multimedia banyak menarik perhatian anak daripada pembelajaran lewat buku. 
- Banyak anak tidak tahu bagaimana menerapkan self-esteem pada lingkungan sehari-hari.

\section{- Oppurtunity}

- Anak-anak lebih tertarik dengan buku yang menarik. Tidak hanya buku berisi tulisan dan gambar saja.

- Anak akan lebih familiar dan lebih mudah menangkap pembelajaran melalui cerita yang dekat dengan mereka.

\section{- Threat}

- Sudah banyak buku tentang bullying.

- Masih belum banyak orangtua mengetahui pentingnya menanamkan self-esteem bagi anak mereka.

- Perkembangan zaman serba memakai gadget.

Strategi yang didapatkan dari analisa di atas sebagai upaya pencegahan dari prilaku bullying adalah merancang buku yang berbasis cerita yang familiar dengan anak sekolah dasar sebagai media dalam mengajarkan self-esteem pada anak. Melalui cerita anak akan lebih mudah dan menangkap nilai-nilai dari self-esteem. Buku yang dibuat juga harus dibuat lebih menarik agar anak tidak mudah bosan. Perancangan buku tidak hanya mengajarkan bullying yang ada di sekeliling mereka namun juga mengajarkan nilai-nilai self-esteem agar anak dapat terhindar dari prilaku tersebut. Dibutuhkan juga perancangan media promosi seperti flyer dan poster yang menjelaskan tentang apa hubungan self-esteem dan bullying agar orangtua tahu manfaat dari buku ini.

\section{PEMBAHASAN}

\section{Media Pembelajaran}

Metode dalam perancangan ini akan menggunakan metode pembelajaran lewat cerita interaktif. Melalui cerita keseharian anak di sekolah yang membuat anak sadar bahwa bullying sudah ada di sekitar mereka. Dalam buku juga mengajarkan anak tentang nilai-nilai self-esteem sebagai upaya pencegahan perilaku bullying. Di dalam buku ini juga ada sarana di mana anak juga ikut berpartisipasi sebagai upaya dalam membangun self-esteem pembaca. Buku dibuat dengan banyak ilustrasi sebagai penunjang dari isi cerita ditambah dengan berbagai sarana interaktif agar lebih menarik perhatian anak dan dapat mengajak anak untuk ikut aktif selama proses pembelajaran sehingga materi yang diberikan dapat diterima secara efektif. Peranan orangtua sangat dibutuhkan untuk menjadi pemandu agar anak lebih mudah mengerti setiap makna yang ada dalam buku. 


\section{Tujuan Kreatif}

Membuat buku interaktif dengan konten yang informatif dan komposisi yang menarik. Tidak hanya berupa tipografi, namun juga dilengkapi dengan interaktif-interaktif yang bisa dimainkan. Materi yang disampaikan dengan menggunakan ilustrasi yang sederhana. Penyampaian buku disampaikan melalui cerita interaktif untuk menyadarkan anak bahwa kasus bullying sudah ada di lingkungan mereka serta melalui buku ini juga dapat meningkatkan nilai-nilai selfesteem yang dimiliki anak sebagai upaya dalam menghindari perilaku bullying.

\section{Strategi Kreatif}

Buku Interaktif merupakan media komunikasi yang tepat untuk memberikan pelajaran pada anak karena tidak hanya berisi pesan namun juga ada sisi interaktifnya dimana anak bisa belajar untuk berimajinasi dan sekaligus sebagai media bermain. Unsur interaktif yang terkandung di dalamnya membuat anak menjadi mudah untuk mengerti dan mengingat nilai-nilai yang disampaikan. Anak bukan hanya belajar namun juga terkandung unsur fun di dalam buku sebagai media penghibur anak. Dalam hal ini penggunaan ilustrasi sangat penting, karena dapat membuat anak lebih jelas memahami isi cerita. Peranan interaktif bisa membuat anak terus terpacu membaca buku sampai selesai.

\section{Sasaran Perancangan}

Karakteristik target audience dalam perancangan ini ditinjau dalam 4 faktor berikut ini:

a. Demografis

Umur: 7-9 tahun

Jenis Kelamin: Laki-laki dan perempuan

Status Sosial: Menengah keatas

Pendidikan: Sekolah Dasar

b. Geografis

Surabaya, Indonesia

c. Psikografis

Hubungan dengan teman sebayanya adalah hal yang penting, mudah terpengaruh, mau belajar karena merasakan dorongan untuk berprestasi, suka mendapatkan penghargaan dari orang lain dan memiliki imajinasi yang kuat.

d. Behaviouristik

Mempunyai keinginan untuk membaca dan menambah wawasan baru

\section{Judul Buku}

Judul buku yang diambil adalah "Aku Berbeda dan Aku Suka”. Penggunaan nama "Aku” pada judul karena tokoh tersebut yang akan menjadi pusat dari keseluruhan cerita. 


\section{Sinopsis}

Self-esteem atau citra diri adalah titik utama dalam masalah bullying. Pelaku bullying tidak mampu memposisikan self-esteem mereka di tengah kelebihan dan kelemahan orang lain. Di sisi lain, korban bullying juga perlu memahami self-esteem pada dirinya sehingga tidak mudah untuk rendah diri. Melalui buku ini anak akan diajak untuk melihat kisah seorang Beti yang berbeda baik secara gaya hidup, fisik dan selera makan. Karena perbedaan tersebut Beti sempat rendah diri di antara teman-temannya. Sampai suatu hari Ibu Guru Beti mengadakan piknik dan semua anak harus membawa bekal makanan. Bagaimanakah kelanjutan cerita Beti? Apakan Beti akan terus diejek? Atau Beti berhasil mengubah cara berpikir teman-temannya?

\section{Tone Warna}

Pada keseluruhan buku akan digunakan warna-warna yang cerah sesuai dengan yang disukai anak-anak usia dibawah 10 tahun pada umumnya. Juga ditambahkan warnawarna seperti abu-abu untuk menunjukkan rasa simpatik dan kesedihan dalam cerita. Penggunaan warna yang cerah pada ilustrasi akan membuat anak tertarik dan meningkatkan minat mereka untuk membaca.

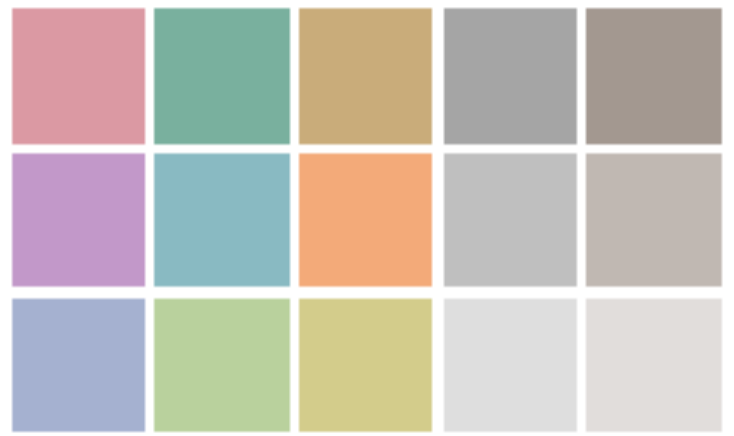

Gambar 1 Tone Warna

Tipografi

- Font Judul

Untuk cover buku ini, jenis font yang digunakan dalam judul adalah font yang mudah dibaca dan menarik perhatian anak. Terkesan playful, dinamis, dan dengan garis tegas cocok untuk anak. Contoh font yang cocok untuk judul dari buku anak adalah:

\section{Aa Bb Ge Dd Ee Ff Gg Hh Ii Jj KK Ll Mm Nn Oo Pp Qq Rr Ss Tt Uu Vv Ww XX YY Zz}

Gambar 2 Font Judul

\section{- Font Teks Narasi}

Sedangkan untuk isi dari cerita dalam buku digunakan font sans serif dengan stroke yang tidak terlalu tebal dan sederhana. Dengan ukuran font sedang membuat anak menjadi lebih nyaman saat membaca buku. Karena apabila font yang digunakan tertalu dekoratif atau terlalu script, itu membuat tulisan menjadi susah dibaca dan malah 
membingungkan anak. Contoh font yang cocok untuk isi dari cerita adalah:

\section{$\mathrm{Aa} \mathrm{Bb} \mathrm{Cc} \mathrm{Dd} \mathrm{Ee} \mathrm{Ff} \mathrm{Gg} \mathrm{Hh} \mathrm{li} \mathrm{Jj} \mathrm{Kk}$ LI $\mathrm{Mm} \mathrm{Nn}$ Oo Pp Qq Rr Ss Tt Uu Vv Ww Xx Yy Zz}

Gambar 3 Font Teks Narasi

\section{Gaya Layout}

Layout yang digunakan adalah penggabungan antara teks, illustrasi dan sarana interaktif yang biasa digunakan dalam buku. Gaya layout yang digunakan untuk buku interaktif ini adalah grid layout. Grid layout digunakan untuk mempermudah dalam penciptaan sebuah komposisi visual. Penggunaan grid layout ini dimaksudkan agar layout tersusun rapi dan memudahkan untuk dibaca. Penggunaan grid layout dalam buku ini lebih terkesan simple karena target dari buku ini adalah anak-anak.

\section{Desain Karakter}

Karakter yang dibuat menggunakan ilustrasi yang sederhana. Ilustrasi sendiri memiliki fungsi memperjelas teks yang ada dan membangkitkan rasa keingintahuan anak. Ilustrasi membuat anak bisa lebih mengerti isi dari cerita dan mempertajam daya imajinasi anak. Gaya visual yang digunakan dalam buku ini adalah gaya visual children. Gaya visual ini adalah gaya yang lebih memfokuskan objek anak akan menjadi elemen utamanya. Gaya ilustasi digunakan adalah gaya ilustrasi buku anak-anak yang lebih mengkesampingkan proposi tubuh dan detail wajah. Setiap karakter mempunyai bentuk rambut yang berbeda-beda dan mempunyai ekspresi dan bentuk wajah yang berbeda-beda sehingga pembaca mudah untuk membedakan setiap karakter.

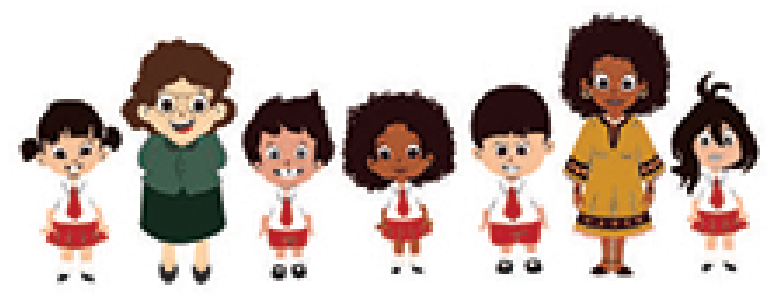

Gambar 4 Desain Karakter

\section{Desain Cergam Final}

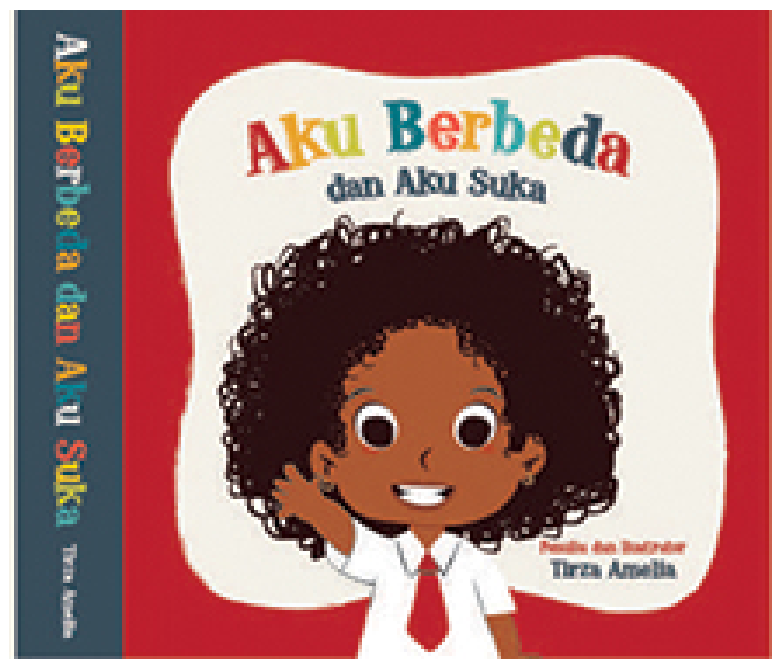

Gambar 5 Cover Depan, Samping 


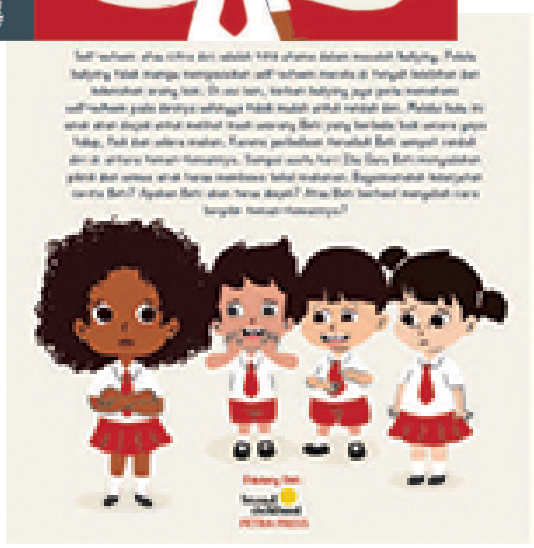

Gambar 6 Cover Belakang

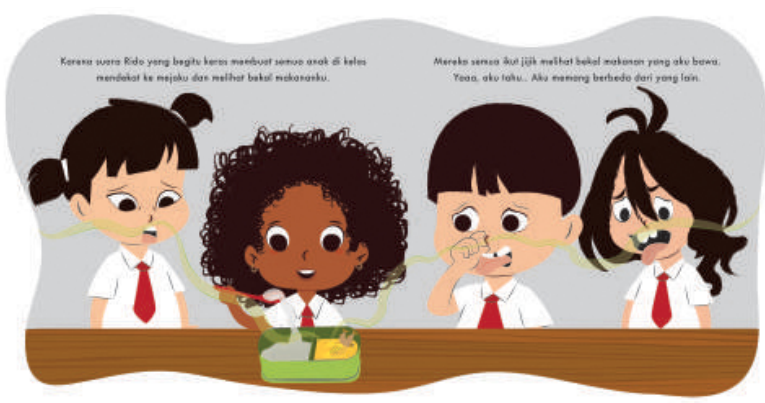

Gambar 7 Salah Satu Halaman Isi Buku

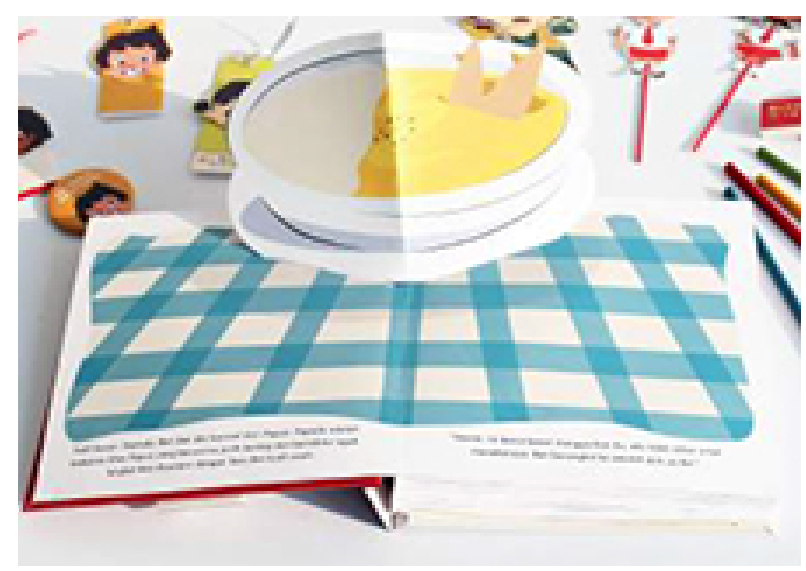

Gambar 8 Gambar 8. Salah Satu Halaman Aplikasi Interaktif Buku 1

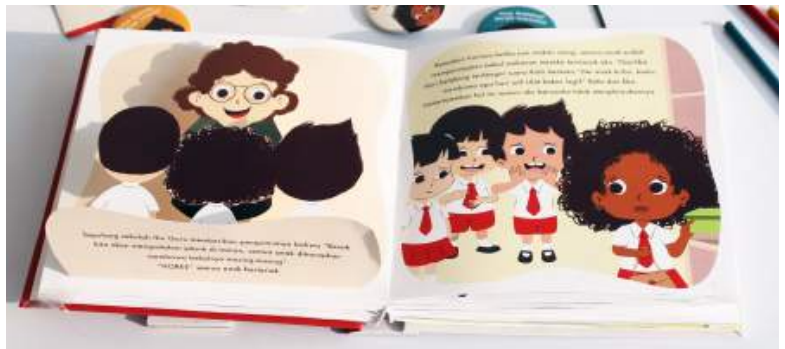

Gambar 9 Salah Satu Halaman Aplikasi Interaktif Buku 2

\section{Media Pendukung dan Promosi Cergam Interaktif}

\section{a. Alat Peraga}

Alat Peraga dibuat berdasarkan setiap karakter yang ada dibuku. Tangan dari karakter bisa digerakkan keatas dan kebawah. Sedangan ekspresi wajah dari setiap karakter bisa di ganti sesuai dengan cerita dalam buku.

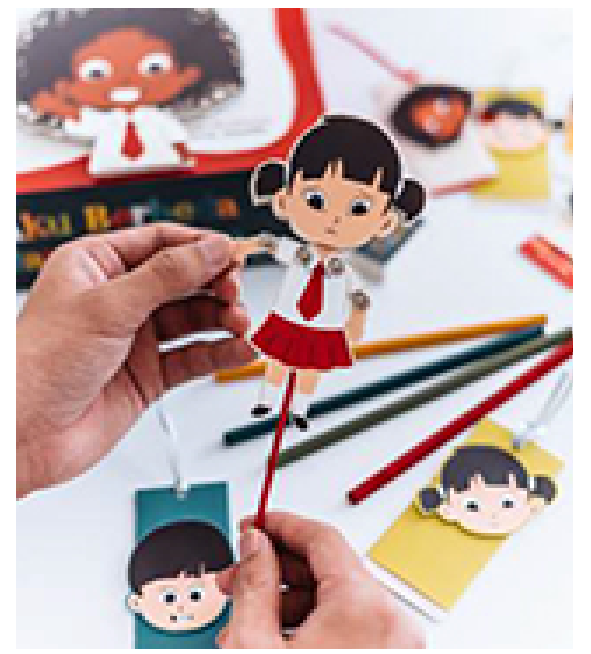

Gambar 10 Alat Peraga 1 


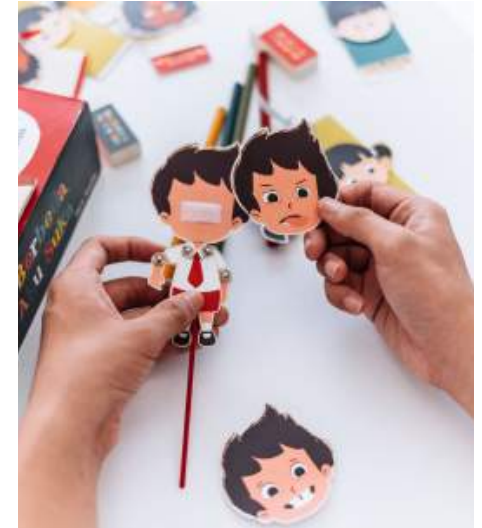

Gambar 11 Alat Peraga 2

\section{b. Packaging}

Desain Kemasan yang dibuat untuk mengemas isi buku dan media peraga yang telah dibuat. Bagian atas adalah tempat untuk buku yang diberi "rel" untuk menyelipkan buku dan kemasan. Sedangan bagian bawah dari packaging adalah box yang berisi alat peraga. Tujuannya sendiri untuk memudahkan dalam proses penjualan. Berikut kemasan dari buku:

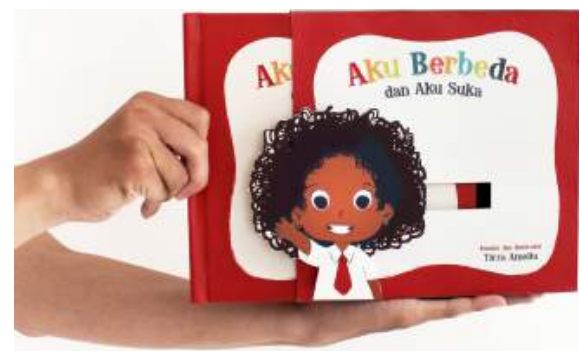

Gambar 12 Kemasan 1

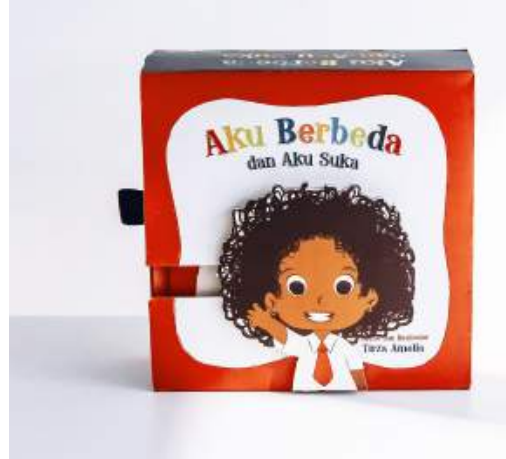

Gambar 13 Kemasan 2

\section{c. Poster Promosi}

Proster promosi buku dibuat interaktif sesuai dengan produk buku interaktif yang ditawarkan. Sisi interaktif juga dibuat untuk lebih menarik perhatian pembeli. Berikut poster promosi "Aku Berbeda dan Aku Suka":

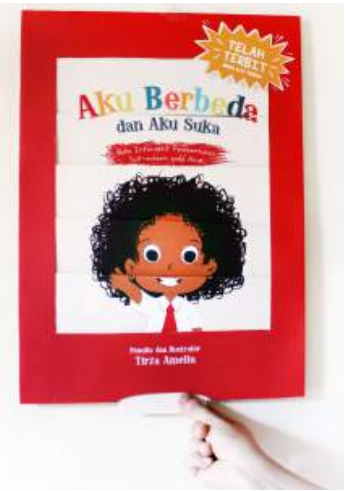

Gambar 14 Poster Promosi 1 


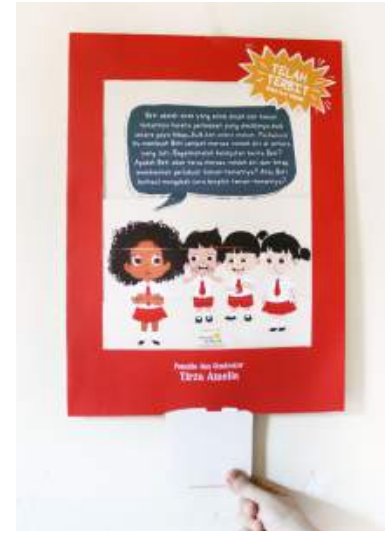

Gambar 15 Poster Promosi 2

\section{d. X-banner}

$X$-banner di desain untuk keperluan dari promosi. X-banner ini nantinya yang akan diletakkan di toko buku sebagai media promosi dari penerbitan buku.

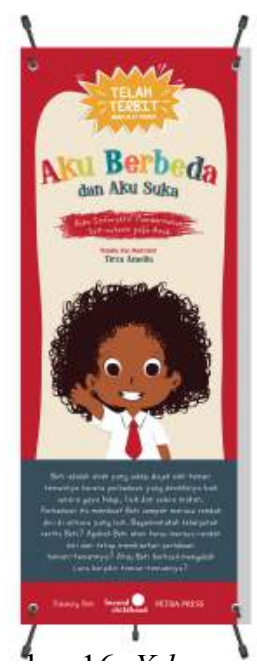

Gambar 16 X-banner

\section{e. Merchandise}

Desain merchandise untuk keperluan promosi buku meliputi: pembatas buku interaktif, pin (berisi slogan-slogan untuk mengingatkan pembaca tentang nilai- nilai self-esteem), pensil dan penghapus (sebagai media penunjang dari buku).

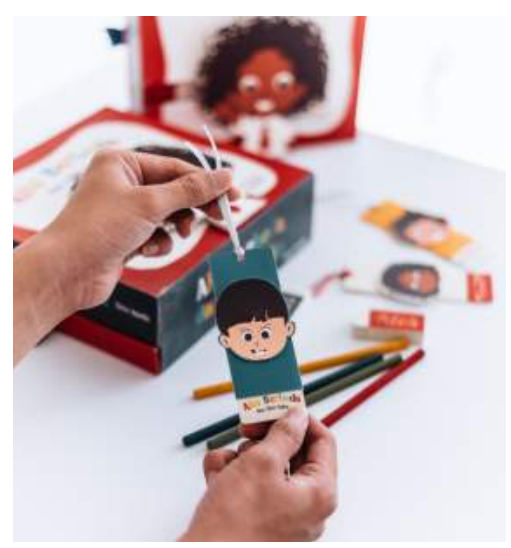

Gambar 17 Pembatas Buku

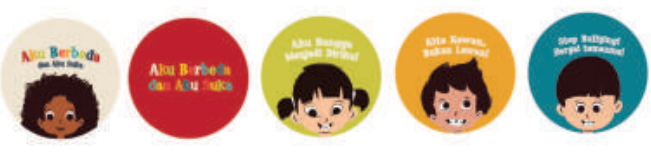
Gambar 18 Pin

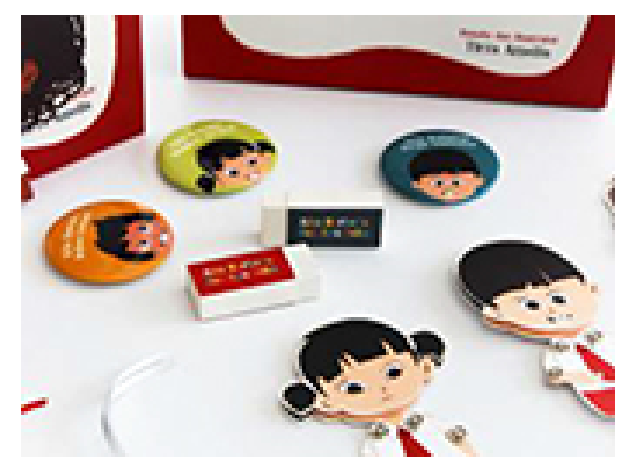

Gambar 19 Penghapus, Pin 


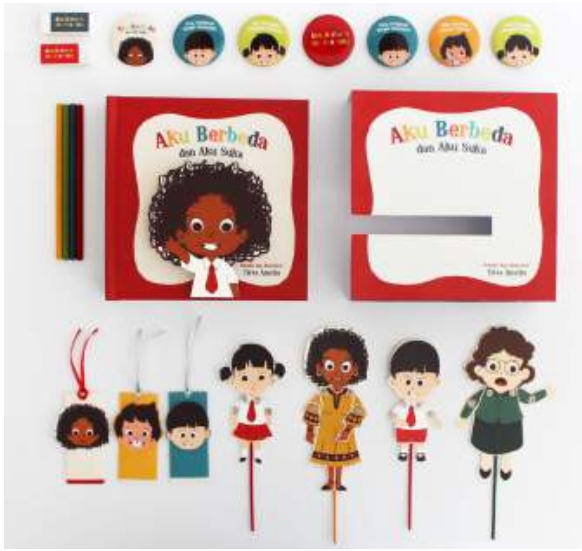

Gambar 20 Merchandise

\section{KESIMPULAN}

Kasus bullying jarang mendapatkan perhatian yang serius. Mayoritas orang menganggap bahwa bullying hanyalah mengakibatkan dampak temporal bagi anak yang akan hilang seiring berjalannya waktu. Namun, menurut hasil penelitian para ahli, dampak bullying dapat mempengaruhi anak seumur hidupnya bila masalah ini tidak diselesaikan dengan baik. Self-esteem dinilai sebagai unsur penting yang perlu dibangun sejak dini untuk mencegah bullying pada anak.

Setelah dilakukan tinjauan lapangan, buku interaktif berbasis cerita anak-anak dianggap sebagai media yang paling tepat dalam upaya peningkatan self-esteem pada anak yang pada akhirnya bertujuan untuk mengurangi jumlah kasus bullying. Melalui cerita yang disampaikan dalam buku "Aku Berbeda dan Aku Suka”, anak-anak diharapkan akan sadar bahwa tindakan bullying adalah tindakan yang salah dan tahu bagaimana cara bertindak ketika mereka mengalami bullying seperti yang dialami oleh tokoh utama. Anak-anak pun diajak menyadari kelebihan dan kelemahan diri sendiri maupun orang lain. Dengan demikian, jumlah kasus bullying diharapkan dapat berkurang.

Pemahaman yang lebih holistik mengenai bullying dan aspek-aspek lain dari bullying, seperti penyebab lain terjadinya bullying dan cara menyikapinya, tentunya sangat penting agar usaha untuk mengurangi jumlah kasus bullying dapat berlangusng lebih efektif. Aspek-aspek ini dapat dikembangkan menjadi dasar perancangan dengan tema bullying yang akan dibuat di masa yang akan datang.

\section{DAFTAR PUSTAKA}

[1] Blanco, Jodee. (2012). Bencana Sekolah!. Jakarta: Pustaka Alvabet.

[2] Branden, Nathaniel. (1994). The Six Pillars Of Self-Esteem. New York: Bantam Books.

[3] Cahyono, C.H \& Suparyo, W. (1985). Tahap-Tahap Perkembangan Moral. Malang: IKIP Malang

[4] Coloroso, B. (2007). Stop Bullying. Jakarta: Penerbit Serambi Ilmu Semesta.

[5] Darmaprawira W.A., Sulasmi. (2002). Warna : Teori dan Kreativitas Penggunaannya. Bandung: Penerbit ITB.

[6] Goodwin, David. (2009). Strategies to Deal with Bullying. North Richmond, NSW: Kidsreach Inc. 
[7] Hurlock, E.B. (1990). Developmental Psychology: A Lifespan Approach. (terjemahan oleh Istiwidayanti). Jakarta: Erlangga

[8] Kartono, Dr. Kartini. (2007). Psikologi Anak (Perkembangan Anak). Bandung: Mandar Maju.

[9] Kurniasih, Imas \& Sani, Berlin (2014). Implementasi Kurikulum 2013 Konsep \& Penerapan. Surabaya: Kata Pena.

[10] Mruk, C.J. (2006). Self-Esteem Research, Theroy, and Practice. Toward a Positive Psychology of Self-Esteem. (3th ed.). New York: Springer Publishing Company.

[11] Makmun (1995). Perkembangan Anak. Bandung: Remaja Rosdakarya.

[12] Pepler, D \& Craig, W. (2002). Making a Difference in Bullying. http://melissainstitute.com/documents/ Making ADifference.pdf.(online).

[13] Piaget, Jean, \& Barbel Inhelder (2010). Psikologi Anak, (Terj. Miftahul Jannah). Yogyakarta: Pustaka Pelajar.

[14] Rigby, Ken (2007). Bullying in School: and what to do about it. Victoria: Acer Press.

[15] Salkind, Neil J. (2004). An Introduction to Theories of Human Development. Thousand Oaks, London. New Delhi: Sage Publications International Education and Publisher.

[16] Sejiwa. (2008). Bullying: Mengatasi Kekerasan di Sekolah dan Lingkungan Sekitar Anak. Jakarta: Grasindo.

[17] Slavin, R.E. (2006) Educational Psychology Theory and Practice. Unites States of America: John Hopkins University.

[18] Triwulandari, Puspita. (2014). Perancangan Buku Pop-up Pentingnya Mengonsumsi Sayursayuran bagi Anak. Jakarta: Telkom University.

[19] Wahyudin, U. \& Agustin, M. (2011). Penilaian Perkembangan Anak
Usia Dini: Panduan untuk Guru, Tutor, Fasilator dan Pengelola Pendidikan Anak Usia Dini. Bandung: Refika Aditama

[20] Wardhani, Rayenda Puti (2015). Skripsi: Perancangan Buku Interaktif Mengenai Miopi Untuk Anak. Surabaya: Petra Christian University,

[21] Williyanto, Fanny (2013). Skripsi: Perancangan Buku Interaktif Pengenalan dan Pelestarian Sugar Glider di Indonesia Bagi Anak 7-12 Tahun. Surabaya: SPetra Christian University. 